\title{
Diversity and Vegetation Analysis of Plant species Associated with Prickly Pear (Opuntia ficus indica L. Mill.) in Nile Delta, Egypt
}

\author{
Ahmed A. Khalafalla ${ }^{1}$, Wafaa M. Said ${ }^{1}$, Sayed Y. Mohamed ${ }^{2}$, Fatema M. Al Saidi $^{1}$ \\ ${ }^{1}$ Botany Department, Faculty of women for Arts, Science and Education, Ain Shams University \\ ${ }^{2}$ Lab Horticulture Research Institute, Agriculture research Center, Agriculture Ministry, Giza
}

\begin{abstract}
The present work aimed to study the floristic diversity and vegetation analysis of weeds associated with Opuntia ficus indica (L.) Mill. in three Nile Delta governorates. Ninety nine stands (10m X 10m) were surveyed in autumn and spring (2015-2016). Seventy one species belonging to 61 genera and 27 families were recorded associated with Prickly Pear. Poaceae, Asteraceae, Chenopodiaceae and Brassicaceae, were the most dominant families. Annuals recorded the highest number of species (45 species) while perennials were represented by 26 species. Therophytes were the dominant life form represented by 43 species while monoregional represented the dominant floristic category (22 species). The application of TWINSPAN on the cover estimates of 71 associated species recorded in the 99 sampled stands of Prickly Pear, led to the recognition of 8 vegetation groups: The names of these groups are: A: Boerhavia Coccinea, B: Cynodon dactylon, C: Cyperus rotundus, D: Psidium guajava, E: Amaranthus lividus, F: Malva parviflora, G: Phragmites australi and H: Imperata cylindrical. M. parviflora group had the highest value of species richness (21.6 species/stand) and relative evenness (0.63), while the highest species turnover (8.2) was recorded in Boerhavia coccenea $\mathrm{VG}$ A and the highest relative concentration of dominance (2.43) was recorded in Amaranthus lividus VG E. Some of the recorded species are invasive and negatively impact Prickly Pear cover, these species need control. Some other species provides many ecological and human services, these species need management and conservation.
\end{abstract}

Key Words: Opuntia ficus indica - Floristic Diversity - Vegetation Analysis - Nile Delta TWINSPAN

\section{Introduction}

Recently biodiversity in agriculture has become a worldwide political issue. The United Nations General Assembly defined the time span of 2011-2020 as the Decade of Biodiversity. The reason for this international interest in biodiversity is the global change and losses of species resulted from industrialization. Biodiversity considerations apply to agriculture and they do not only refer to crops but to associated species also (Kraehmer $\boldsymbol{e} t$ al., 2016).

The plant community plays an important role in sustainable management by maintaining biodiversity and conserving the environment (Kandi et al. 2011). A major objective of most weed community ecology studies has been to identify the patterns of species composition and distribution and to interpret these patterns in relation to known or presumed gradients in the environment (Fried et al. 2008).

- Corresponding author: Fafirosek@yahoo.com 
Quantitative analysis, especially quantitative classification methods and ordination techniques, has been used widely to indicate the ecological relationships between vegetation and the environment (Zhang \& Zhang 2000). Moreover, floristic studies are not only important in order to know the variety of plants that is present in an area, but because plants are socioeconomically significant. They provide shelter, food, medicine and everything for the human being and other species of that area.

Weeds are unwanted plant species emergent in the cultivated crops and grow where they are not needed. Out of 8000 only 250 weed species are important for agriculture world (Holm et al., 1979). Weeds cause great destruction to crops as they increase the costs of different cultural practices, decrease the effectiveness of agricultural equipment and excellence of fertile lands, decrease the germination capability of crops seed due to the phytotoxins or allelochemicals (Algandaby and Salama, 2016).

In some circumstances, weeds and associated species to crops can reduce soil erosion, slow nutrient loss, increase soil organic matter, improve nitrogen levels and conserve soil water. Weeds that have proportionally deeper rooting systems relative to co-occurring crops may be capable of significant net transfer of nutrients from deep soil layers not available to such crops (Patriquin, 1986). In addition to their ecological value, many authors pointed out there importance in animal feeding, human consumption, medical uses, biological control, phytoremediation and phytoextraction (Borgio et al., 2007; Dkhil et al., 2011; Shelef et al., 2013; Golzardi et al., 2015; Al-Snafi, 2015; Al-Oqai et al., 2016; Biswas et al., 2016).

Native to Latin America, Opuntia ficus indica (L.) Mill. commonly named prickly pear, is a long-domesticated cactus crop that is important in agricultural systems throughout arid and semiarid parts of the world (Anderson, 2001). It has been introduced in the Mediterranean basin in the 15th century (Donkin, 1977). The species is well known for its ability to grow in dry and even desert conditions and its cultivation has been especially important in marginal and subsistence economies (Feugang, 2006). Commercial plantations are concentrated in Spain, Italy, Mexico, Brazil, Chile, Argentina, and USA (Basile, 2001). Prickly pear plants are used in a variety of ways, such as food and beverage, feed, medicinal and dyeing (Pimienta and Muñoz-Urias, 1995). Seed oil of prickly pear is exceptionally valuable because of its high content of essential fatty acids such as linoleic acid (omega-6), Vitamin E (around $1000 \mathrm{mg} / \mathrm{kg}$ ) and sterols (around $10 \mathrm{~g} / \mathrm{kg}$ ) (Ennouri et al, 2006).

Vegetation Study of Opuntia ficus indica orchards in Egypt has not received suitable attention in respect to its importance. So, this work aimed to study the floristic composition and vegetation analysis of associated species with prickly pear (Opuntia ficus indica) in some habitats of Nile Delta region.

\section{Materials and Methods}

\subsection{Floristic analysis}

Twelve sites of Opuntia ficus indica located at three governorates (Qalyubiya represented by orchards, Minufiya along train Road of Cairo-Alexandria (Berket Al Saboa) and Buhayrah along the sides of Abo Mangug-Shobrakheet road] were selected to study vegetation associated with Opuntia ficus indica (fig. 1). 
Vegetation data were collected during autumn and spring seasons at 2015 and 2016, respectively. Ninety nine (each $10 \times 10 \mathrm{~m}$ ) were selected randomly along the selected sites. A list of species of the orchard floor was made for each sampled stand. The cover of each species was visually estimated as a percentage using Réléve method (Muller-Dombois and Ellenberg, 1974). Identification and nomenclature were according to Täckholm (1974), Boulos and El-Hadidi (1984), El-Hadidi and Fayed (1994-1995) and Boulos (1999, 2000, 2002, 2005 and 2009). The voucher specimens were deposited in faculty of women, botany Department Herbarium Ain Shams University.

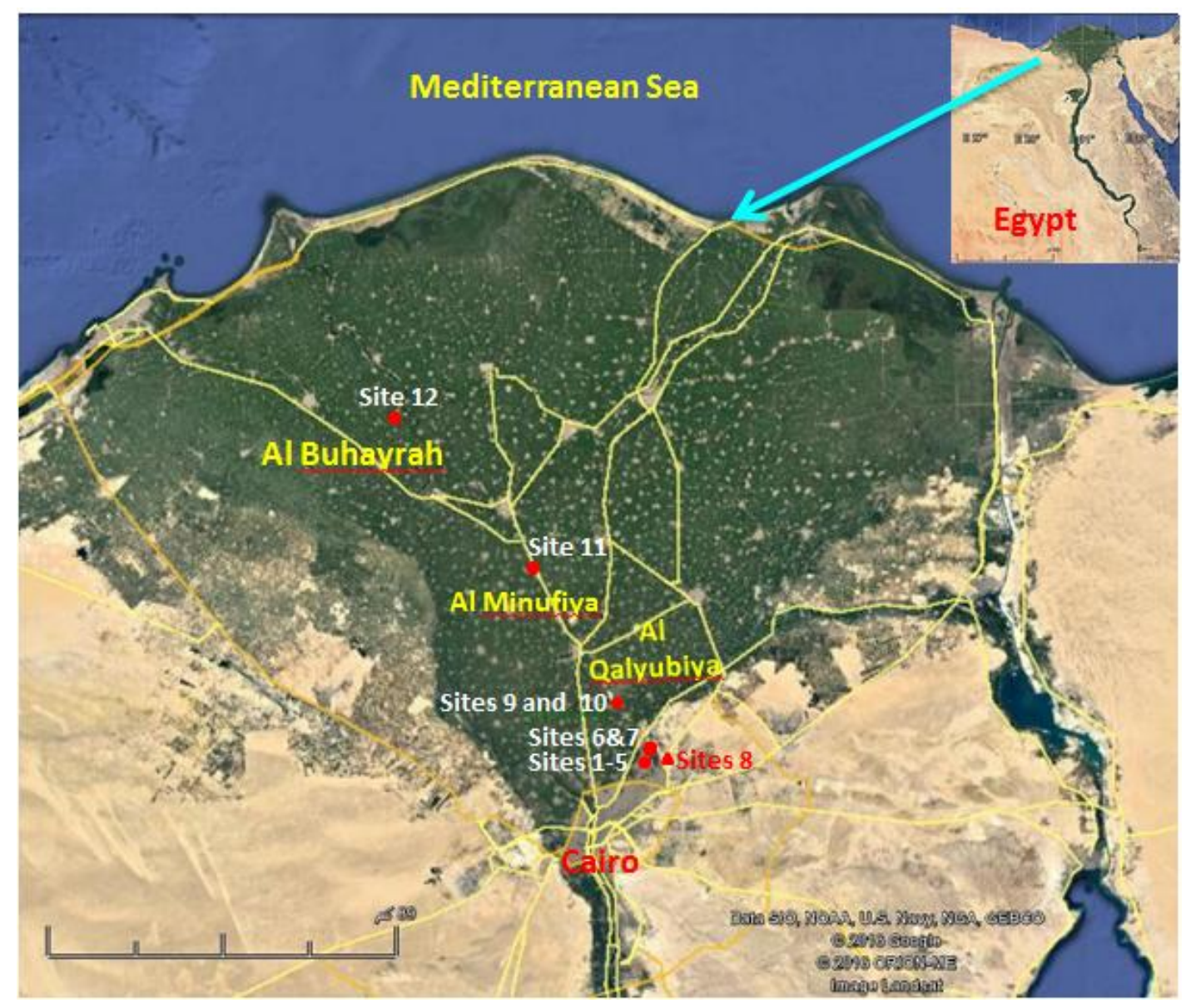

Fig. 1: Study sites (Google Earth map, 2015)

\subsection{Multivariate analysis}

Two-way indicator species analysis (TWINSPAN) as a classification technique and Detrended Correspondence Analysis (DCA) as an ordination technique were applied to the matrix of cover estimates of 71 species in 99 stands in Opuntia ficus indica farms. TWINSPAN is a two-way classification FORTRAN program that constructs a key to the sample classification by identifying one to several species that are particularly diagnostic of each division in the classification. The most significant new feature is that the program first constructs a classification of samples, and then uses this classification to obtain a classification of species according to their ecological preferences (Hill, 1979a; Gauch, 1980; Gauch and Whittaker, 1981). DCA is a FORTRAN program for detrended correspondence 
analysis and reciprocal averaging. It was applied as a mean of axis construction to achieve a two-dimentional ordination of species and stands (Hill, 1979b; Hill and Gauch, 1980).

\subsection{Diversity indices}

Some diversity indices were calculated for the vegetation groups as derived from the multivariate analysis. Species richness (alpha-diversity) for each vegetation group was calculated as the average number of species per stands. Species turnover (beta-diversity) was calculated as a ratio between the total number of species recorded in a certain vegetation group and its alpha diversity (Whittaker, 1972). Relative evenness or equitability (ShannonWiener index) of the species cover was expressed as $\hat{H}=-\Sigma^{\mathrm{S}} \mathrm{P}_{\mathrm{i}}\left(\log \mathrm{P}_{\mathrm{i}}\right)$, where $\mathrm{S}$ is the total number of species and $\mathrm{P}_{\mathrm{i}}$ is the relative cover of the species. The relative concentration of dominance is the second group of heterogeneity indices and is expressed by Simpson's index: $\mathrm{D}=1 / \mathrm{C}\left\{\mathrm{C}=\Sigma^{\mathrm{s}}\left(\mathrm{P}_{\mathrm{i}}\right)^{2}\right\}$, where $\mathrm{S}$ is the total number of species and $\mathrm{P}_{\mathrm{i}}$ is the relative cover of species (Pielou, 1975; Magurran, 1988).

\section{Results}

\subsection{Flora and Vegetation}

\subsubsection{Floristic analysis}

Seventy one species belonging to 61 genera and 27 families were recorded associated with $O$. ficus indica (Table 1). The most dominant family was Poaceae, represented by 16 species, Asteraceae (10 species), Chenopodiaceae (5 species), Brassicaceae (4 species) Solanaceae, Amaranthaceae, Euphorbiaceae and Fabaceae, (each 3 species, Apiaceae, Amaryllidaceae, Convolvulaceae and Polygonaceae (each 2 species), and each of the other families were represented by one species (Fig 2).

\section{Habit of species}

Annual plants represented the highest number of species (45 species) associated to $O$. ficus indica, while perennial plants represented by 26 species (Fig. 3).

\section{Life forms}

The life form spectra of the recorded species associated with $O$. ficus indica indicated the presence of eight life forms: therophytes, chamaephytes, hemicryptophytes, geophyteshelophtes, phanerophytes, geophytes, helophytes and Parasites (Fig. 4). It was found that, therophytes were the dominant life form represented by 43 species, while geophyteshelophtes were represented by 7 species, hemicryptophytes (6 species), phanerophytes and chamaephytes (5 species), geophytes (3 species), helophytes and Parasites each one were represented by a single species.

\section{Chorological analysis}

The spectrum of the global distribution of the recorded species associated with $O$. ficus indica indicated that monoregional taxa were the dominant elements; represented by 22 species followed by bi-oregional and pluri-regional (15 species), cosmopolitans (14 species) and 5 species of cultivated elements (Fig. 5). 


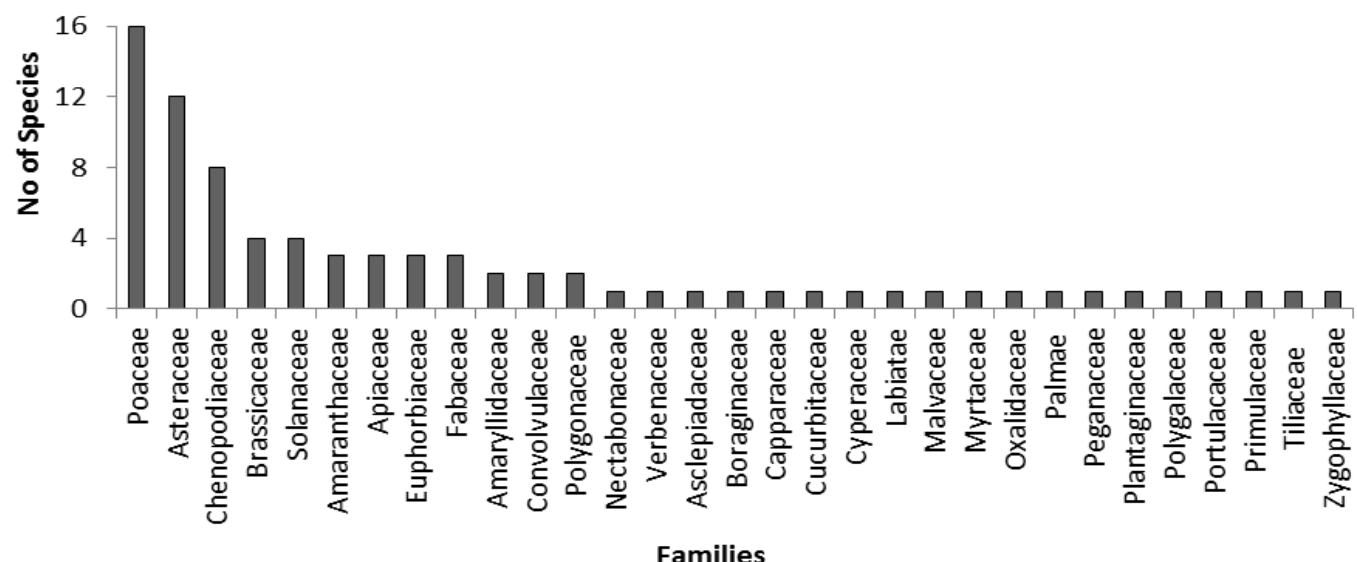

Fig. 2. Number of plant species belonging to the different families associated with Opuntia $s p$.

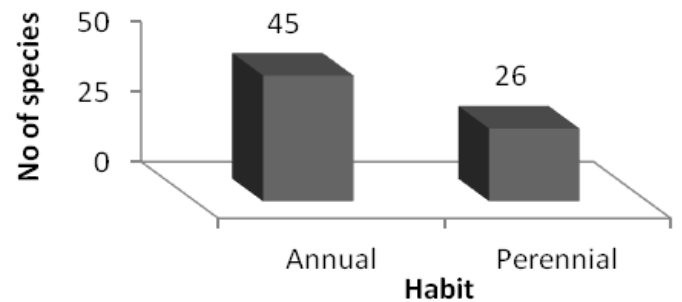

Fig. 3. Habit of the recorded species associated with Opuntia sp.

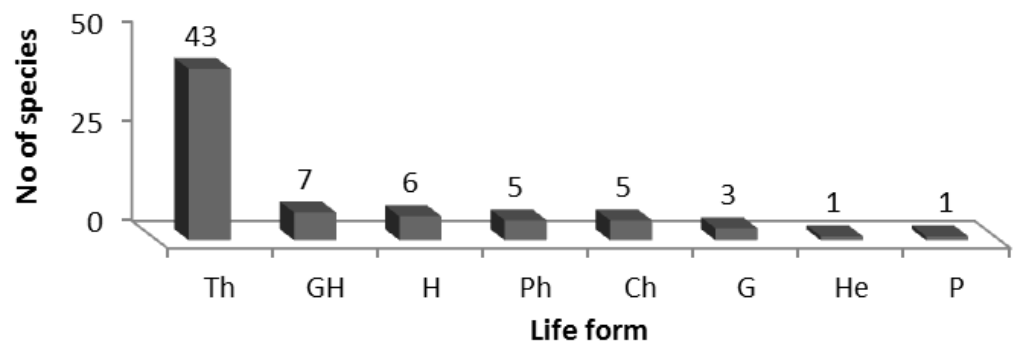

Fig. 4. Life form spectra of the recorded associated species in each of Opuntia sp. Th: therophytes, GH: geophyte - helophytes, H: hemicryptophytes, Ph: phanerophytes, Ch: chamaephytes, G: geophytes, He: helophytes and P: Parasite.

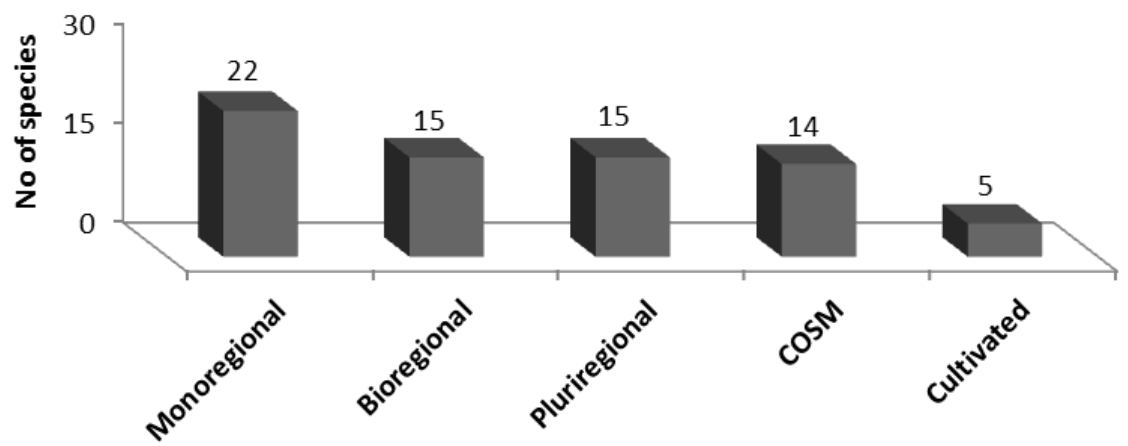

Floristic category

Fig. 5. Floristic category of the recorded species associated with Opuntia sp. 
Table 1. Floristic properties of the recorded species associated with Opuntia ficus indica

\begin{tabular}{|c|c|c|c|c|c|}
\hline Species & Family & Arabic name & Habit & $\begin{array}{l}\text { Life } \\
\text { form }\end{array}$ & $\begin{array}{l}\text { Floristic } \\
\text { category }\end{array}$ \\
\hline Emex spinosa (L.) Campd & Polygonaceae & حنزاب & Annual & Th & ME + SA-SI \\
\hline Portulace aleracea $\mathrm{L}$. & Portulacaceae & رجله & Annual & Th & COSM \\
\hline Beta vulgaris $\mathbf{L}$. & Chenopodiaceae & 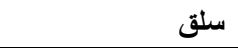 & Annual & Th & ME+ER-SR+IR-TR \\
\hline Chenopodium album $\mathrm{L}$. & Chenopodiaceae & زربيج ابيض ابيض - & Annual & Th & COSM \\
\hline Chenopodium glaucum $\mathbf{L}$. & Chenopodiaceae & سرمق - زربيح & Annual & Th & ME+ER-SR \\
\hline Chenopodium murale $\mathbf{L}$. & Chenopodiaceae & 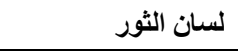 & Annual & Th & COSM \\
\hline Bassia indica (Wight.) A.J.Scott. & Chenopodiaceae & كوخيا & Annual & Th & IR-TR+S-Z \\
\hline Amaranthus hypridus $\mathrm{L}$. & Amaranthaceae & رعاف & Annual & Th & COSM \\
\hline Amaranthus lividus $\mathbf{L}$. & Amaranthaceae & أمارنطون & Annual & Th & ME+IR-TR \\
\hline Amaranthus viridis $\mathbf{L}$. & Amaranthaceae & قطيفة مذنبه & Annual & Th & COSM \\
\hline $\begin{array}{l}\text { Gynandropsis gynandra (L.) } \\
\text { Briq. }\end{array}$ & Cleomaceae & ابو قرن & Annual & Th & PAL \\
\hline Sisymbrium irio L. & Brassicaceae & سمارة رثة & Annual & Th & ME+IR-TR+ER-SR \\
\hline Brassica nigra (L.) Koch & Brassicaceae & خردل اسود & Annual & Th & COSM \\
\hline Eruca sativa Mill. & Brassicaceae & جرجير & Annual & Th & CULT and NAT \\
\hline $\begin{array}{l}\text { Coronopus niIoticus (Delile) } \\
\text { Spreng. }\end{array}$ & Brassicaceae & 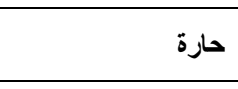 & Annual & Th & S-Z \\
\hline Melilotus indicus (L.) All. & Fabaceae & حندقوق هندي & Annual & Th & ME+IR-TR+SA-SI \\
\hline Alhagi graecorum Boiss. & Fabaceae & 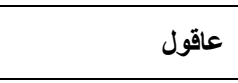 & Perennial & Ch & $\begin{array}{l}\text { ME+IR-TR+SA- } \\
\text { AR+S-Z }\end{array}$ \\
\hline Dalbergia sissoo Roxb. & Fabaceae & السرسوع & Perennial & $\mathbf{P h}$ & Cultivated \\
\hline Oxalis corniculata $\mathrm{L}$. & Oxalidaceae & حميضة قرينية & Perennial & $\mathrm{He}$ & COSM \\
\hline Tribulus terrestris $\mathbf{L}$. & Zygophyllaceae & الحسك & Annual & Th & PAN \\
\hline Ricinus communis $\mathbf{L}$. & Euphorbiaceae & 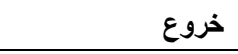 & Perennial & $\mathbf{P h}$ & PAN \\
\hline Euphorbia heterophylla $\mathbf{L}$. & Euphorbiaceae & فربيون - حلبلوب & Annual & Th & PAN \\
\hline Euphorbia peplus L. & Euphorbiaceae & فرفيون بيلوس - & Annual & Th & ME+ER-SR+IR-TR \\
\hline $\begin{array}{l}\text { Polygala hohenackeriana Fisch. } \\
\text { \& c. A. Mey. }\end{array}$ & Polygalaceae & 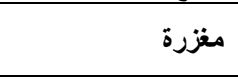 & Perennial & $\mathbf{H}$ & SA-SR \\
\hline Corchorus olitorius $\mathbf{L}$. & Tiliaceae & ملوخيه & Annual & Th & PAN \\
\hline Malva parviflora $\mathrm{L}$. & Malvaceae & 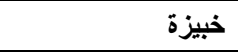 & Annual & Th & ME+IR-TR \\
\hline $\begin{array}{l}\text { Cucumis prophetarum L. subsp. } \\
\text { dissectus (Naudin) C. JetTrey }\end{array}$ & Cucurbitaceae & خيار الذيب & Perennial & $\mathbf{H}$ & $\mathbf{S A}+\mathbf{S Z}$ \\
\hline Ammi majus L. & Apiaceae & خلة ـ سدا & Annual & Th & ME+IR-TR \\
\hline Apium graveolens $L$ & Apiaceae & شبت & Annual & Th & Cultivated \\
\hline AnagaIiis arvcnsis $\mathbf{L}$. & Primulaceae & زغلتت ـ عين القط & Annual & Th & COSM \\
\hline Cynanchum acutum $\mathrm{L}$. & Asclepiadaceae & 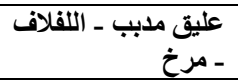 & Perennial & Ch & ME+IR-TR \\
\hline Convolvulus arvensis $\mathrm{L}$. & Convolvulaceae & عليق بري & Perennial & $\mathbf{H}$ & Trop \\
\hline Cuscuta planiflora Ten. & Cuscutaceae & حامول البرسيخ - حامول & Annual & $\mathbf{P}$ & ME+SA-SR+IR-TR \\
\hline Echium rauwolfii Delile. & Boraginaceae & زالثورة الافعى - لسان & Annual & Th & SA \\
\hline Phyla nodiflora $\mathrm{L}$. & Verbenaceae & ليبيا & Perennial & $\mathbf{H}$ & ME+IR-TR+Trop \\
\hline Boerhavia coccennea $\mathbf{L}$. Mill & Nectagonaceae & & Perennial & Ch & SA-AR+S-Z \\
\hline
\end{tabular}


Table 1. continue

\begin{tabular}{|c|c|c|c|c|c|}
\hline Species & Family & Arabic name & Habit & $\begin{array}{l}\text { Life } \\
\text { form }\end{array}$ & $\begin{array}{l}\text { Floristic } \\
\text { category }\end{array}$ \\
\hline Solanum nigrum $\mathrm{L}$. & Solanaceae & عنب الايب & Annual & Ch & $\begin{array}{l}\text { ME+ER-SR+ } \\
\text { IR-TR }\end{array}$ \\
\hline Solanum lycopersicum $\mathbf{L}$. & Solanaceae & طماطم & Annual & Th & Cultivated \\
\hline Datura innoxia Mill & Solanaceae & داتوره- عين الجمل & Annual & Th & NEO \\
\hline Plantago major $\mathrm{L}$. & Plantaginaceae & 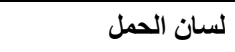 & Perennial & $\mathbf{H}$ & COSM \\
\hline Pluchea dioscorides (L.) Desf. & Asteraceae & برنوف & Perennial & $\mathbf{P h}$ & SA-AR+S-Z \\
\hline $\begin{array}{l}\text { Conyza bonariensis }(\mathrm{L} .) \\
\text { Cronquist }\end{array}$ & Asteraceae & خوع- نفلا & Annual & Th & NEO \\
\hline $\begin{array}{l}\text { Symphotrichum squamatum } \\
\text { (Spreng.) Nesom }\end{array}$ & Asteraceae & 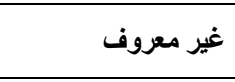 & Annual & Ch & Trop \\
\hline Xanthium strumarium $\mathbf{L}$. & Asteraceae & الثبيط - اللزيق & Annual & Th & PAN \\
\hline Bidens pilosa $\mathbf{L}$. & Asteraceae & ذو السنبيَنْ ـ حُسيكة & Annual & Th & PAN \\
\hline $\begin{array}{l}\text { Verbesina encelioides (Cov.) } \\
\text { Benth. }\end{array}$ & Asteraceae & القراص ـ المحرق & Annual & Th & PAN \\
\hline $\begin{array}{l}\text { Senecio glaucus L. subsp. } \\
\text { coronopifolius (Maire) C. } \\
\text { Alexander }\end{array}$ & Asteraceae & الشيخة الرمادية & Annual & Th & ME+SAAR+IR-TR \\
\hline $\begin{array}{l}\text { Cichorium endivia L. subsp } \\
\text { pumilum Jacq. }\end{array}$ & Asteraceae & شيكريس - الكبر- & Annual & Th & ME+IR-TR \\
\hline Launaea nudicaulis (L.) Hook. & Asteraceae & حوا & Perennial & $\mathbf{H}$ & SA-AR+IR-TR+S-Z \\
\hline Sonchus oleraceus $\mathbf{L}$. & Asteraceae & جعضيض & Annual & Th & COSM \\
\hline Allium neapolitanum Cyr. & Amaryllidaceae & ابيض نابولي - ثُوم & Perennial & Th & ME+SA-SR \\
\hline Allium cepa $\mathrm{L}$. & Amaryllidaceae & بصل & Perennial & GH & Cultivated \\
\hline Phoenix dactylifera $\mathrm{L}$. & Palmae & نظلة التمر & Perennial & $\mathbf{P h}$ & Cult - SA-AR+S-Z \\
\hline Avena fatua $\mathrm{L}$. & Poaceae & شوفان & Annual & Th & COSM \\
\hline Phalaris minor Retz. & Poaceae & ذيل القط & Annual & Th & ME+IR-TR \\
\hline Bromus catharticus Vahl. & Poaceae & & Annual & Th & $\begin{array}{l}\text { ME+ER-SR+IR-TR } \\
+ \text { +MA }\end{array}$ \\
\hline Phragmites australis (Cav.)Trin. & Poaceae & بوص & Perennial & GH & COSM \\
\hline $\begin{array}{l}\text { Desmostachya bipinntata }(\text { L.) } \\
\text { Stapf }\end{array}$ & Poaceae & حلفا - سخبر & Perennial & G & SA-SI+S-Z \\
\hline Cynodon dactylon (L.) Pers. & Poaceae & نجيل بلاي & Perennial & G & COSM \\
\hline Panicum repens $\mathrm{L}$. & Poaceae & الزاحفام المنتفخ - الثمام & Perennial & G & PAN \\
\hline Echinochloa colona (L.) Link & Poaceae & ابو ركبه ـ ذنيبه & Annual & Th & ME+IRTR+Trop \\
\hline Setaria verticillata $(\mathrm{L}$.$) Beauv.$ & Poaceae & ذيل الثعلب & Annual & Th & COSM \\
\hline Setaria viridis $(\mathbf{L}$.$) Beauv$ & Poaceae & الخشب الاخضر & Annual & Th & PAL \\
\hline $\begin{array}{l}\text { Paspalidium geminatum } \\
\text { (Forssk.) Stapf }\end{array}$ & Poaceae & نسيله - أبو بيض & Perennial & GH & Trop \\
\hline Digitaria sanguinalis (L.) Scop. & Poaceae & ابوركبة & Annual & Th & PAL \\
\hline Cenchrus echinatus $\mathrm{L}$. & Poaceae & سبط قنففي & Annual & Th & Trop \\
\hline $\begin{array}{l}\text { Imperata cylindrica (L.) } \\
\text { Raeusch. }\end{array}$ & Poaceae & حلفا ـ حلف ـ ديس & Perennial & GH & ME+SA-AR+IR-TR \\
\hline $\begin{array}{l}\text { Dichanthium annulatum } \\
\text { (Forssk.) Stapf. }\end{array}$ & Poaceae & عثب هندي - دياز & Perennial & GH & PAL \\
\hline Vossia cuspidata (Roxb.) Griff. & Poaceae & غير معروف & perennial & GH & Trop \\
\hline Cyperus rotundus $\mathrm{L}$. & Cyperaceae & سعد & Perennial & GH & ME+IR-TR+Trop \\
\hline Psidium guajava $\mathrm{L}$. & Myrtaceae & جوافة & Perennial & $\mathbf{P h}$ & Cultivated \\
\hline
\end{tabular}




\subsection{Vegetation Analysis}

The application of TWINSPAN on the cover estimates of 71 associated species recorded in the 99 sampled stands of $O$. ficus indica led to the recognition of 8 vegetation groups (Fig. 6). These groups showed a reasonable segregation along the ordination plane axes 1 and 2 of DECORANA (Fig. 7). It is noticed that the first six vegetation groups represents the sites located at $\mathrm{Al}$ Qalyubiya governorates, while the $7^{\text {th }}$ group contains the stands along the sides of Cairo-Alexandria train road (Berkat Al-Saboa site, Minufiya) and the $8^{\text {th }}$ group contains the stands along the sides of Abo Mangug-Shobrakheet road (Buhayrah). The vegetation groups are named after the first dominant species associated with O. ficus indica (the species that have the highest presence percentage and/or the highest cover). The presence of $O$. ficus indica was $100 \%$ in all vegetation groups, while cover varied from one group to another. The description of these vegetation groups was indicated as follows:

A: Boerhavia coccenea, it includes 43 stands and 34 species, Opuntia Ficus-indica covered $62.9 \%$ in this group where Cynodon dactylon represented by $7.6 \%$ cover and $100 \%$ presence and Boerhavia coccenea represented by $1.4 \%$ cover and $46.5 \%$ presence. Cynanchum acutum, Verbesina encelioides, Launaea nudicaulis, Panicum repens, Setaria viridis and Chenopodium album are common associated weeds. On the other hand, Gynandropsis gynandra, Polygala hohenackeriana, Allium neapolitanum and Cucumis prophetarum are recorded only in this vegetation group of the ten groups.

B: Cynodon dactylon, it includes 10 stands and 32 species. In this group Opuntia Ficusindica represented by $37.9 \%$ cover, Cynodon dactylon (29.0\%) 100\%, the common associated weeds to this vegetation group are Cynanchum acutum, Alhagi graecorum, Avena fatua, Amaranthus viridis, Ricinus communis, Cyperus rotundus, while Dalbergia sissoo, and Xanthium strumarium are recorded only this vegetation group.

C: Cyperus rotundus, this group contains 11 stands and 26 species. In this group Opuntia Ficus-indica covered $65.0 \%$, Cynodon dactylon covered $5.7 \%$ and presented by $100 \%$ and Cyperus rotundus cover $1.3 \%$ and presented by $81.8 \%$. The common associated weeds are Amaranthus lividus, Amaranthus viridis, Avena fatua and Boerhavia coccenea.

D: Psidium guajava, it contains 8 stand and 31 species. In this stand Opuntia ficus-indica represented by $71.3 \%$ cover, while Cynodon dactylon represented by $3.8 \%$ cover and $100 \%$ presence and Psidium guajava represented by $2.0 \%$ cover and $100 \%$ presence. Paspalidium geminatum, Cyperus rotundus, Amaranthus viridis, Amaranthus viridis and Verbesina encelioides are the common associated weeds, while Echinochloa colona, Phoenix dactylifera and Psidium guajava are foun in this vegetation group.

E: Amaranthus lividus, it contains 8 stands and 40 species. In this group Opuntia Ficusindica represented by $50.6 \%$ cover, but Cynodon dactylon represented by $8.4 \%$ cover and $100 \%$ presence and Amaranthus lividus by $4.4 \%$ cover and $100 \%$ presence. The common associated groups to this group are Cyperus rotundus, Amaranthus viridis, Chenopodium murale, Avena fatua, Sonchus oleraceus and Setaria verticillata, while Eruca sativa, Bromus catharticus, Beta vulgaris, Senecio glaucus and Phalaris minor recorded only in this vegetation group.

F: Malva parviflora, it contains 9 species and 44 species. Opuntia Ficus-indica represented by $27.8 \%$ cover while Cynodon dactylon represented by $19.9 \%$ cover and $100 \%$ presence and 
Malva parviflora represented by $1.2 \%$ cover and $100 \%$ presence. The common associated weeds to this vegetation group are Amaranthus lividus, Amaranthus viridis, Avena fatua, Corchorus olitorius and Emex spinosa. Six weeds were recorded only in this vegetation group (Cichorium endivia, AnagaIiis arvcnsis, Anethum graveolens, Coronopus niloticus, Melilotus indicus and Plantago major)

G: Phragmites australi, it contains the 5 stand of site 12 (Abo Mangog road, Al- Baihara Governorate) and 8 species. In this group, Opuntia Ficus-indica represented by $54.0 \%$ cover while Phragmites australis represented by $7.0 \%$ cover and $100 \%$ presence and Ricinus communis represented by $2.2 \%$ cover and $100 \%$ presence. Cynodon dactylon, Bassia indica, Amaranthus lividus and Cynanchum acutum are the common associated weeds to this vegetation group.

H: Imperata cylindrical, it contains the 5 stands of site 11 (Berket Al-Saboa, Monefia Governorate) and 11 species. In this group, Opuntia Ficus-indica represented by $60.0 \%$ cover while Phragmites australis represented by $8.0 \%$ cover and $100 \%$ presence. Cynodon dactylon, Pluchea dioscorides, Imperata cylindrical and Convolvulus arvensis. Phyla nodiflora is the weed species which found in this vegetation group of the ten groups.

\subsection{Diversity of the plant communities}

The total number of species recorded in the 8 vegetation groups, identified according to TWINSPAN classification technique, varied from 44 species in $C$. dactylon and $M$. parviflora group (VG F) to 26 species in Cyperus rotundus group (VG C). M. parviflora group (VG F) had the highest value of species richness (21.6 species/stand), while VG A had the lowest values of species richness (4.2 species/stand). The highest species turnover (8.2) was recorded in VG A while the lowest in VG G. VG F had the highest value of relative evenness (0.63), while the highest relative concentration of dominance (2.43) were recorded in VG E (Table. 2). 


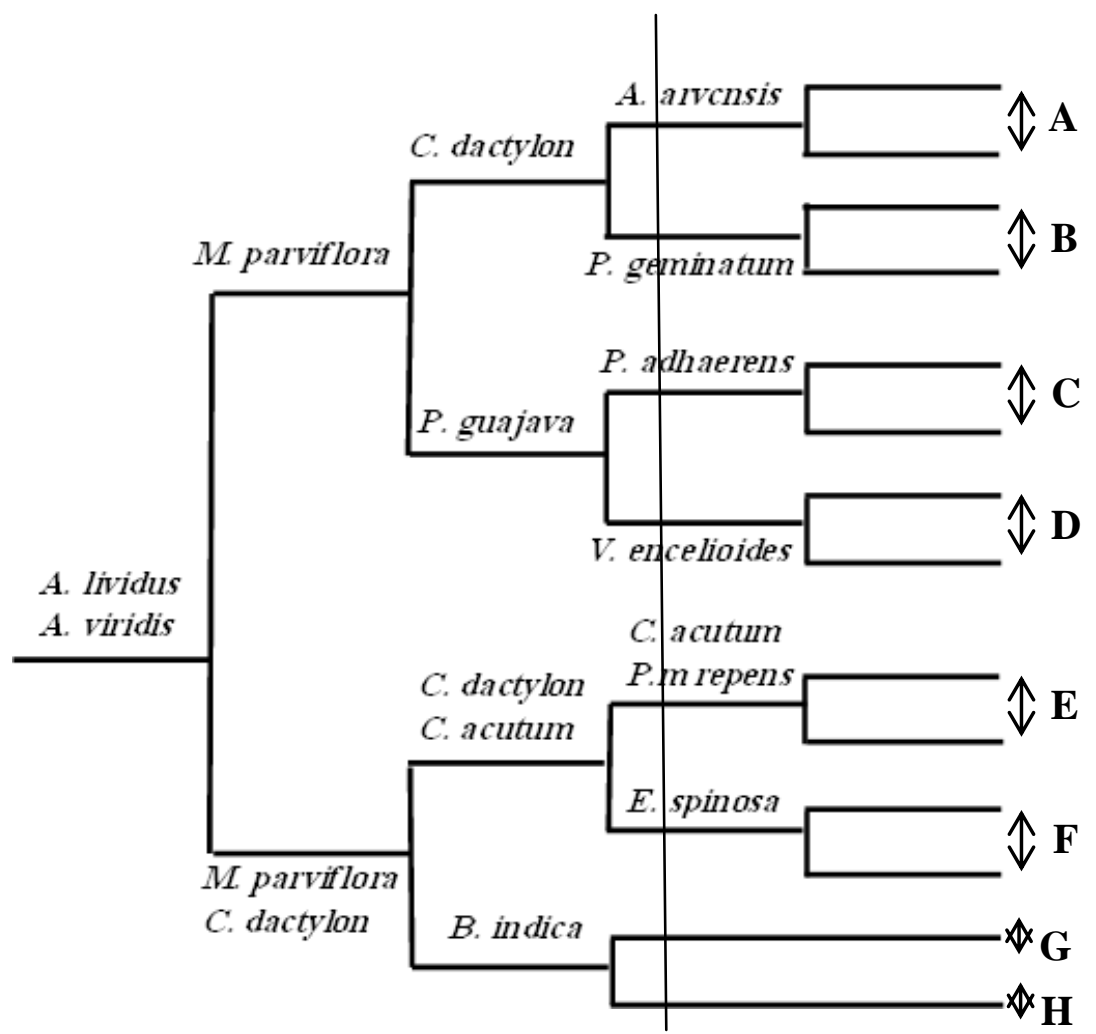

Fig. 6. The dendrogram resulting from the application of TWINSPAN on the 99 sampled stands. The names of these groups are: A: Boerhavia coccenea, B: Cynodon dactylon, C: Cyperus rotundus, D: Psidium guajava, E: Amaranthus lividus, F: Malva parviflora, G: Phragmites australi and $\mathbf{H}$ : Imperata cylendrica.

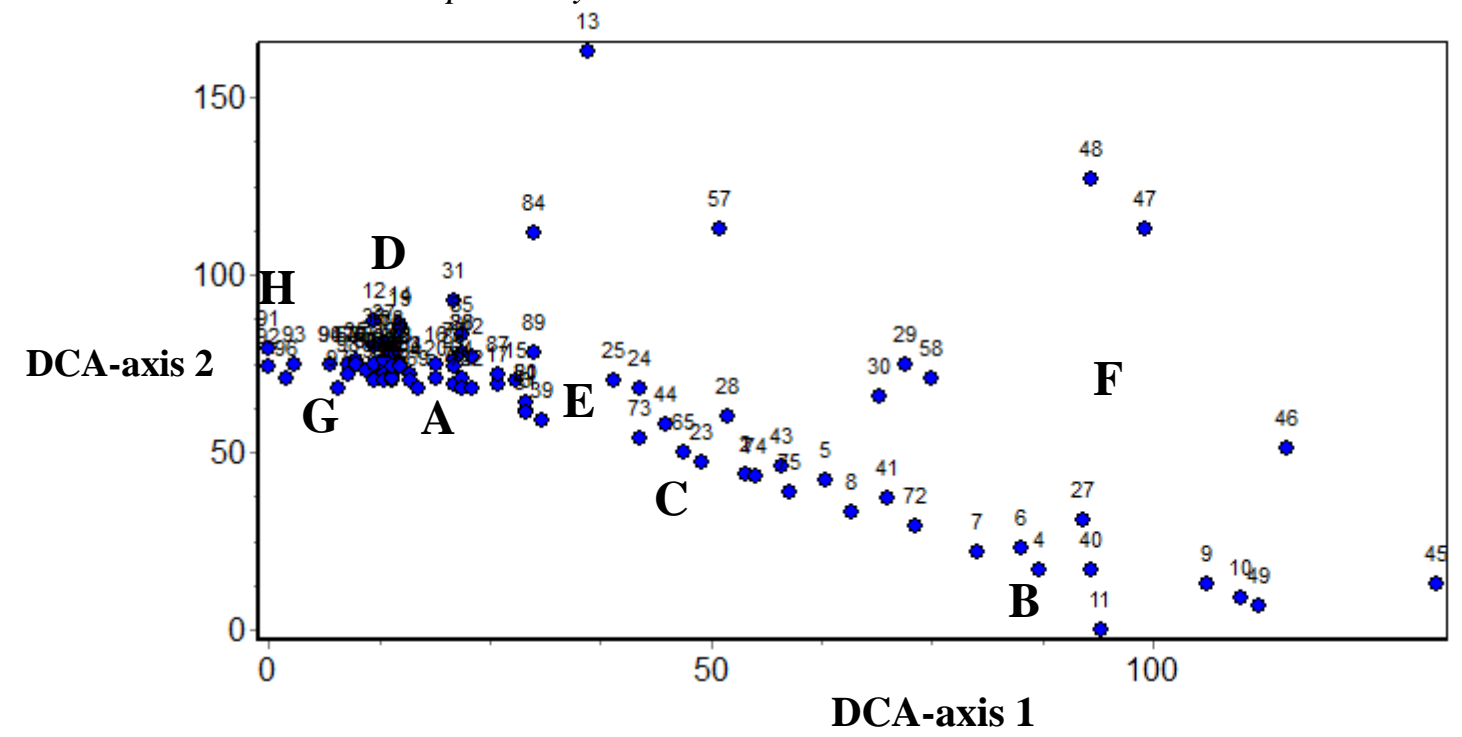

Fig. 7: DCA ordination of the 8 vegetation groups identified after the application of TWINSPAN on the 99 sampled stands. The names of these groups are: A: Boerhavia coccenea, B: Cynodon dactylon, C: Cyperus rotundus, D: Psidium guajava, E: Amaranthus lividus, F: Malva parviflora, G: Phragmites australi and $\mathbf{H}$ : Imperata cylendrica s. 
Table 2: Diversity indices of the 8 vegetation groups produced from TWINSPAN. Maximum are bold and underlined and minimum values are italic and underlined. A: Boerhavia coccenea, B: Cynodon dactylon, C: Cyperus rotundus, D: Psidium guajava, E: Amaranthus lividus, F: Malva parviflora, G: Phragmites australi and $\mathbf{H}$ : Imperata cylendrica

\begin{tabular}{|l|c|c|c|c|c|c|c|c|}
\hline Diversity idex & Veg A & Veg B & Veg C & Veg D & Veg E & Veg F & Veg G & Veg H \\
\hline Number of species & 34.0 & 32.0 & 26.0 & 31.0 & 40.0 & $\mathbf{4 4 . 0}$ & 8.0 & 11.0 \\
Species richness & 4.2 & 8.1 & 8.6 & 14.4 & 19.0 & $\mathbf{2 1 . 6}$ & 7.4 & 6.0 \\
Species turnover & $\mathbf{8 . 2}$ & 4.0 & 3.0 & 2.2 & 2.1 & 2.0 & 1.1 & 1.8 \\
$\begin{array}{l}\text { Relative evenness } \\
\text { Relative concentration } \\
\text { of dominance }\end{array}$ & 0.44 & 0.55 & 0.37 & 0.40 & 0.55 & $\mathbf{0 . 6 3}$ & 0.19 & 0.28 \\
\hline
\end{tabular}

\section{Discussion}

Little database about associated species of Opuntia ficus indica populations in Egypt and worldwide are available. Flora of the study sites represented 71 species of the Egyptian flora where they are belonging to 61 genera and 27 families. Poaceae represented the most dominant plants associated with $\mathrm{O}$. ficus indica communities, followed by Asteraceae, Chenopodiaceae, Brassicaceae and Fabaceae. These families constitute the main bulk of the flora of the study area in according to Springuel (1990), Speringuel $\boldsymbol{e t}$ al. (1991) and Ali $\boldsymbol{e t}$ al. (1995) in the Nile Valley (Upper Egypt), Al-Sodany (1992) in various habitats in north Nile Delta, and Khedr and Hegazy (1998) in the north western part of Nile Delta and Khalafallah et al. (2016) middle Nile Delta.

The plant life form is usually understood to be a growth form which displays an obvious relationship to important environmental factors. The life form spectra of the recorded species associated with $O$. ficus indica showed that therophytes were the dominant life form where it represented by $60.6 \%$ of the total recorded species, followed by geophyteshelophytes $(9.9 \%)$, hemicryptophytes $(8.5 \%)$, phanerophytes and chamaephytes each life form represented by $7.0 \%$, Geophytes $(4.2 \%)$ and Helophytes and Parasite each life form represented by $1.4 \%$. According to Galal (2001), therophytes are the main life forms and most of them are weed species characteristic to the cultivated lands, coinciding with Hassib (1951) on the Egyptian flora. Heneidy and Bidak (2001) pointed out that the dominance of therophytes over the other life forms seems to be a response to the hot-dry climate, topographic variation and biotic influence. The present study indicated that annuals recorded 45 species (63.4\% of the recorded species). Khalafalla et al. (2016) found that annuals associated with wheat and maize crops represented 89.7 and $73.9 \%$ of the total recorded species. Gomaa (2012) attributed the high contribution of annuals to their short life cycle that enables them to resist the instability of the agro-ecosystem. Annuals are generally characterized by high allocation of resources to the reproductive organs and the production of flowers early in their life-span to ensure some seed production even in a year when the growing season is cut short (Sans and Masalles, 1995). However, Marshall (1989) demonstrated that most perennial species are not adapted to successful establishment in arable crops.

The spectrum of the global distribution of the recorded species associated with $O$. ficus indica orchards appeared that monoregional taxa were the dominant species $(30.99 \%$ of 
the total recorded species), followed by bi-regionals and pluri-regional (each category recorded $21.13 \%$ ), cosmopolitans $(19.82 \%)$ and cultivated elements $(7.04 \%)$. The present result is in consistent with the results of Khalafallah et al. (2016), where they found that mono-regional taxa were the dominant elements in maize crops in Middle Delta. According to Mashaly (1987), 50\% of the species in the Deltaic sector are Mediterranean taxa, 32\% are pluri-regionals, and $8 \%$ are Saharo-Sindian elements. In the present study, Mediterranean taxa were the main category $(30.99 \%)$ in the study area, however presence of phytogeographical elements other than Mediterranean is believed to be a reflection of intense climatic changes and/or the degradation of the Mediterranean ecosystem which facilitated the invasion of some elements from the adjacent regions (Mashaly, 1987; Madi et al., 2002).

In Egypt, phytosociological studies on weeds along the Nile valley are still limited. In fact, most of the studies that carried out on weed communities are mostly floristic (Shaltout et al., 1992; Galal, 2001). Phytosociologists used ordination techniques to simplify distribution patterns along the gradients of environmental variables (Springuel and Murphy, 1991; Spink, 1992). The classification of vegetation associated with $O$. ficus indica orchards, using TWINSPAN analysis, resulted in identifies 8 vegetation groups. C. dactylon is a common community associated with $O$. ficus indica. This classification may indicate the significant effect of habitat type, management practices, seasonality and soil characteristics, these factors influence weed community composition (Légere and Samson, 1999; Leeson $\boldsymbol{e t}$ al., 2000; Gomaa, 2012).

$C$. dactylon and co-dominance between $C$. dactylon and other species dominated $O$. ficus indica orchards. This indicated that $C$. dactylon can tolerant and survive in different condition as pointed out by Sieben et al. (2016) that $C$. dactylon is the main vegetation group in their study to wetlands in inundated and non-inundated conditions. The grass $C$. dactylon is not only tolerant to inundation, but also to salinity (Hameed and Ashraf, 2008), which is important in the wetlands of arid regions (Johns et al., 2014). C. dactylon and its codominants were represented by 6 communities distributed in 10 sites of $O$. ficus indica orchards located at Qalyubiya governorate. These sites had different practices for weed control and showed different coverage of $O$. ficus indica. O. ficus indica orchard of site 7 (Ezbet Shokry, Abo Za'able, Qalyubiya) subjected to application of herbicide (Herbazed 48\%) additionally, they had high cover \% of O. ficus indica (averaged 84\%) these factors leads to reducing the number of weed species. On the other hand, the stands distributed in young $O$. ficus indica orchards (Ezbet Al-Abiad, Abo Za'able, Qalyubiya) and cultivated with Alium сера crop characterized by wide spaces and regular irrigation showed high number and cover of weed species. The present results showed negative correlation between the cover percentage of $O$. ficus indica and the associated weeds. This correlation has reversible effect on the Opuntia cover and associated species. Phragmites australis, C. dactylonm, I. cylendrica and $C$. acutum showed harsh effect on the coverage area of $O$. ficus indica, while increasing in coverage area of $O$. ficus indica can decreased the cover and diversity of other weeds. Consequently the rhizomatous or climbing weeds are strong competitor reduced growth and spatial distribution of Opuntia, while Opuntia is strong competitor against sallow roots and annual weeds. $C$. acutum

From the field study and the knowledge from farmers it was noted that habitat type, season, soil type, weed management, agricultural practices, Opuntia cover and application of 
herbicides had the most significant influence on species composition. It clear that low cover of Opuntia highly leads to increase in number of species, high species richness, high relative evenness and high relative concentration of dominance as recorded for $C$. dactylon and $M$. parviflora vegetation group. But high cover of Opuntia resulted in reducing diversity indices except species turnover increased as shown for $B$. coccenea vegetation group.

Lawlor (2003), Douglass et al. (2009) and Weston et al. (2005) reported that the invasion of Cynanchum species and their waste conspicuously got to be ubiquitous through the farmlands, gardens (especially in perennial plants cultivation) and also in zero-tillage management system. Their higher invasive power due to; they can generate immense number of winged seeds to spread away by wind for many kilometers (Lawlor, 2003; Douglass et al., 2009; Blanchard et al., 2010; Hotchkiss et al., 2008); The higher proportion of root to shoot (Smith, 2006); production and extraction of allelo-chemicals compositions (Weston et al., 2005; Cappuccino, 2004; DiTommaso et al., 2005).

The high species richness may be related to this environmental micro-heterogeneity that promotes diversity (Palmer and Maurer, 1997). The variations in species richness, diversity and evenness among the different community types may be attributed to differences in soil characteristics, substrate discontinuities and the allelopathic effects of one or more invasive species depending on their relative dominance among other associated species (James et al., 2006; Galal and Shehata, 2015; Khalafallah et al., 2016). Moreover, the difference in field management practices may also be a factor that explains differences in weed species richness (Stevenson et al., 1997; Sher and Al-Yemeni, 2011; Gomaa, 2012). Although weeds are unwanted plants, increased their diversity may have other indirect beneficial effects on agro-ecosystems. For example, increased vegetation diversity can lead to suppression of pests via 'top-down' enhancement of natural enemy populations or by resource concentration and other 'bottom-up' effects acting directly on pests (Tracy et al., 2004; Galal and Shehata, 2015).

Average species richness of 8 vegetations groups in $O$. ficus indica (11.2) was higher than that recorded by Khalafallah et al. (2016) in wheat crop (10.9) and Soliman (2016) in maize (10.0), in orchards (olive and date palm) by Gomaa (2012) and in farms (8.0) by ElShiekh (2013). The high species richness of this study compared with crops and olive and date palm orchards and farms may be attributed to the fact that the land of Opuntia orchards rarely plowed a practice that reduces the richness of weeds (Gomaa, 2012).

The present study recorded 71 species associated with $O$. ficus indica orchards, most of these species have medicinal uses, phytoremediation and phytoextractions, cattle feeding, human foods and other uses (Dkhil et al., 2011; Borgio et al., 2007; Shelef et al., 2013; Golzardi et al., 2015; Al-Snafi, 2015; Al-Oqai et al., 2016; Biswas et al., 2016) . In addition to their drastic effects on the useful weeds and the main production of Opuntia (vegetative parts and fruits) and their poisoning threats to cattle (Schmutz et al. 1968; Holm et al., 1977; Lawlor, 2003; Douglass et al., 2009). Maximizing the use of weed and increased production of prickly pears must apply the natural methods to ameliorate the impact of harmful weeds and manage and conserve the useful species. 


\section{Conclusion}

Seventy one species were recorded in 99 stand distributed in $O$. ficus indica L. Mill. populations. The recorded species are belonging to 61 genera and 27 families. Poaceae is the most dominant family, Therophytes were the dominant life form and the monoregional represented the dominant floristic category. Eight vegetation groups were recognized by application of TWINSPAN on the cover of 71 associated species recorded in 99 stands of Prickly Pear. Most of the recorded species have ecological and human uses, these species need management and conservation. While other species are invasive and have drastic effect on Opuntia Plants, these species need control.

\section{6- References}

Algandaby, M.M. and Salama, M. Management of the noxious weed; Medicago polymorpha L. via allelopathy of some medicinal plants from Taif region, Saudi Arabia. Saudi J. Biol. Sci. Accepted, (2016).

Ali, M.M., Hamad, A.M., Springuel, I. and Murphy, K.J. Environmental Factors Affecting Submerged Macrophyte Communities in Regulated Water Bodies in Egypt. Arch. Hydrobiol., 133: 107-128 (1995).

Al-Oqai, M.M., Siddiqui, M.A., Al-Sheddi, E.S., Saquib, Q., Musarrat, J. , AlKhedhairy, A.A. and Farshori, N.N. Verbesina encelioides: cytotoxicity, cell cycle arrest, and oxidative DNA damage in human liver cancer (HepG2) cell line. BMC Complement Altern Med. 16: 126 (2016).

Al-Snafi A.E. Alhagi maurorum as A Potential Medicinal Herb: an Overview. International Journal of Pharmacy Review \& Research, 5(2): 130-136 (2015).

Al-Sodany, Y.M. Vegetation analysis of the northern part of Nile Delta region. M. Sc. Thesis, Tanta University, Tanta. 122 pp. (1992).

Anderson, E.F. The cactus family. Timber Press, Portland, Oregon, USA (2001).

Anderson, EF (2008). The Catcus Family. Timber Press, Portland, OR, 776 pp.

Anderson, EF (2008). The Catcus Family. Timber Press, Portland, OR, 776 pp.

Basile, F (2001). Economic aspects of Italian cactus pear production and market. J PACD 4: 31-49.

Basile, F (2001). Economic aspects of Italian cactus pear production and market. J PACD 4: 31-49.

Basile, F. Economic aspects of Italian cactus pear production and market. J PACD 4: 31-49 (2001).

Biswas, T.K., Pandit., S., Chakrabarti, Sh., Banerjee, S., Poyra, N.and Sea, T. Evaluation of Cynodon dactylon for wound healing activity. Journal of Ethnopharmacology. In Press, Corrected Proof, Available online 22 July 2016.

Blanchard, M.L., Barney, J.N. Averill, K.M. Mohler, C.L. and DiTommaso, A.D. Does polyembyrony confer a competitive advantage to the invasive perennial vine Vincetoxicum rossicum (Apocynaceae)? Am. J. Bot., 97: 251-260 (2010).

Borgio, J., Thorat, P. and Lonkar, A. Antimycotic and Antibacterial activities of Gynandropsis pentaphylla DC extracts and its Phytochemical Studies. The Internet Journal of Microbiology, 5(2): 1-7 (2007).

Boulos, L. and El-Hadidi, M.N. Common Weeds in Egypt. Dar El-Maaraf, Cairo (1967).

Boulos, L. Flora of Egypt Checklist, Revised Annotated Edition. Al Hadara Publishing, Cairo, Egypt (2009). 
Boulos, L. Flora of Egypt. Vol. I (Azollaceae - Oxalidaceae). Al Hadara Publ, Cairo, Egypt, 419 pp. (1999).

Boulos, L. Flora of Egypt. Vol. II (Geraniaceae - Boraginaceae). Al Hadara Publ, Cairo, Egypt,352 pp. (2000).

Boulos, L. Flora of Egypt. Vol. III (Verbinaceae - Compositae). Al Hadara Publ, Cairo, Egypt,373 pp. (2002).

Boulos, L., El-Hadidi, M.N. The Weed Flora of Egypt. American Univ. Cairo Press, Cairo, 178 pp. (1984).

Cappuccino, N. Allee effect in an invasive alien plant, pale swallowwort Vincetoxicum rossicum (Asclepiadaceae). Oikos, 106: 3-8 (2004).

De Kock, GC (1980). Drought resistant fodder shrub crops in South Africa. In: Le Houérou H. N. (Ed.)Browse in Africa: The current state of knowledge. International livestock center of Africa, Addis-Ababa,399-410.

De Kock, GC (1980). Drought resistant fodder shrub crops in South Africa. In: Le Houérou H. N. (Ed.)Browse in Africa: The current state of knowledge. International livestock center of Africa, Addis-Ababa,399-410.

DiTommaso, A., Lawlor, F.M. and Darbyshire, S.J. The biology of invasive alien plants in Canada. 2. Cynanchum rossicum (Kleopow) Borhidi [5 Vincetoxicum rossicum (Kleopow) Barbar.] and Cynanchum louiseae (L.) Kartesz and Gandhi [5 Vincetoxicum nigrum (L.) Moench]. Can. J. Plant Sci., 85:243-263 (2005).

Dkhil, M.A., Abdel Moniem, A.E. Al-Quraishy, S. and Saleh, R.A. Antioxidant effect of purslane (Portulaca oleracea) and its mechanism of action. Journal of Medicinal Plants Research, 5(9): 1589-1563 (2011).

Donkin, $R$ (1977). Spanish red: an ethnogeographical study of cochineal and the Opuntia cactus. Trans AmerPhil Soc 67: 1-77.

Donkin, R (1977). Spanish red: an ethnogeographical study of cochineal and the Opuntia cactus. Trans AmerPhil Soc 67: 1-77.

Donkin, R. Spanish red: an ethnogeographical study of cochineal and the Opuntia cactus. Trans AmerPhil Soc 67: 1-77 (1977).

Douglass, C.H., Weston, L.A. and DiTommaso, A. Black and pale swallowwort (Vincetoxicum nigrums and V. Rossicum): the biology and ecology of two perennial, exotic and invasive vines. Pages 261- 276 inInderjit, ed. Management of Invasive Weeds. New York: Springer Science + Business Media B.V. (2009).

El-Hadidi, M.N. and Fayed, A.A. Materials for Excursion Flora of Egypt. Täckholmia, 15: 1-223 (1994-1995).

Ennouri, M, Fetoui, H, Bourret, E, Zeghal, N, and Attia, H (2006).Evaluation of some biological parameters of Opuntia ficus indica. Influence of a seed oil supplemented diet on rats. Bioresour Technol 97:1382-1386.

Ennouri, M, Fetoui, H, Bourret, E, Zeghal, N, and Attia, H (2006).Evaluation of some biological parameters of Opuntia ficus indica. Influence of a seed oil supplemented diet on rats. Bioresour Technol 97:1382-1386.

Ennouri, M., Fetoui, H., Bourret, E., Zeghal, N. and Attia, H. Evaluation of some biological parameters of Opuntia ficus indica. Influence of a seed oil supplemented diet on rats. Bioresour Technol 97:1382-1386 (2006).

Feugang, J.M., Konarski, P., Zou, D., Stintzing, F.C. and Zou, C. Nutritional and medicinical use of cactus pear (Opuntia spp.) cladodes and fruits. Front Biosci 11: 2574-2589. (2006) 
Feugang, JM, Konarski, P, Zou, D, Stintzing, FC,and Zou, C (2006).Nutritional and medicinical use of cactus pear (Opuntia spp.) cladodes and fruits. Front Biosci 11: 2574-2589.

Feugang,JM, Konarski,P, Zou, D, Stintzing, FC, and Zou, C.Nutritional and medicinical use of cactus pear (Opuntia spp.) cladodes and fruits. Front Biosci 11: 2574-2589 (2006).

Fried G., Norton L.R. and Reboud X. Environmental and management factors determining weed species composition and diversity in France. Agr. Ecosys. Environ. 128: 68-76 (2008).

Galal, T.M. and Shehata, H.S. Impact of nutrients and heavy metals capture by weeds on the growth and production of rice (Oryza sativa L .) irrigated with different water sources. Ecological Indicators, 54: 108-115 (2015).

Galal, T.M. Studies on the River Nile Vegetation in El Kahira El Kobra. MSc. Thesis, Faculty of Science, Helwan University, Cairo, Egypt. 187 pp. (2001).

Gauch, H.G. and Whittaker, R.H. Hierarchical Classification of Community Data. J. Ecol., 69: 135-152 (1981).

Gauch, H.G. Multivariate Analysis in Community Ecology, Cambridge Univ. press, Cambridge, 298 pp. (1980).

Golzardi, F., Vaziritabar, Y., Vaziritabarm, Y., Asilan, K.S, Ebadi, S.Z., Sarvaramini, Sh., Sayadi, M.H.J. Allelopathic Effect of Two Cynanchum acutum L. Populations on Emergence and Shoot Development of Barley. J. Appl. Environ. Biol. Sci., 5(1):166175 (2015).

Gomaa, N.H. Composition and diversity of weed communities in Al-Jouf province, northern Saudi Arabia. Saudi journal of biological sciences, 19(3): 369-76 (2012).

Hameed, M. and Ashraf, M. Physiological and biochemical adaptations of Cynodon dactylon (L.) Pers. from the salt range (Pakistan) to salinity stress. Flora, 203: 683-694 (2008).

Hassib, M. Distribution of Plant Communities in Egypt. Bull. Fac. Sci., Fouad I Univ., 29: 59-261 (1951).

Heneidy, S.Z. and Bidak, L.M. Multipurpose Plant Species in Bisha, Asir Region, Southwestern Saudi Arabia. J. Biol. Sci., 7 (6): 1010-1023 (2001).

Hill, M. O. and Gauch, H.G. Detrended Correspondence Analysis, an Improved Ordination Technique. Vegetatio, 42: 47-58 (1980).

Hill, M.O. DECORANA: AFORTRAN Program for Detrended Correspondence Analysis and Reciprocal Averaging: Cornell Univ., Ithaca, New York, 52 pp (1979b).

Hill, M.O. TWINSPAN: A FORTRAN Program for Arranging Multivariate data in an Ordered To-way Table by Classification of the Individual and Attributes. Cornell Univ., Ithaca, New York, 90 pp (1979a).

Holm, L., Pancho, J., Herberger, J. and Plucknett, D. A Geographical Atlas of World Weeds. John Wiley and Sons, New York.(1979).

Holm, L.G., Plucknett, D.L., Pancho, J.V., Herberger, J.P. The World's Worst Weeds. University Press (1977).

Hotchkiss, E.E., DiTommaso, Brainard, A.D.C. and Mohler, C.L. Survival and performance of the invasive vine Vinctoxicum rossicum (Apocynaceae) from seeds of different embryo number under two light environments. Am. J. Bot., 95:447-453 (2008).

James, C.S., Eaton, J.W. and Hardwick, K. Responses of three invasive aquatic macrophytes to nutrient enrichment do not explain their observed field displacements. Aquat. Bot., 84: 347-353 (2006). 
Johns, C., Ramsey, M., Bell, D. and Vaughton, G. Does increased salinity reduce functional depth tolerance of four non-halophytic wetland macrophyte species? Aquatic Botany, 116: 13-18 (2014).

Kandi B., Sahu S.C., Dhal N.K. and Mohanty R.C. Species diversity of vascular plants of Sunabeda wildlife sanctuary, Odisha, India. N.Y. Sci. J. 4, 1-9 (2011).

Khalafallah, A.A., Galal, T.M., Naim, M.A. and Soliman, M.A. Composition of Weed Communities Associated with Wheat Crops in Menofia Provence, Egypt. Annual Review- Faculty of Women for Arts, Sicence and Education, Ain Shams University, Accepted (2016).

Khedr, A.A. and Hegazy, A.K. Ecology of the rampant weed Nymphaea lotus L. Willdenow in natural and ricefield habitats of the Nile Delta. Egypt. Hydrobiol., 386: 119-129 (1998).

Kraehmer, H, Jabran, K, Mennan, H. and Chauhan, B.S. Global distribution of rice weeds: A review. Crop Protection, 80: 73-86 (2016).

Lawlor, F. M. The swallowworts. N.Y.Forest Owner, 41:14-15 (2003).

Leeson, J.Y., Sheard, J.W. and Thomas, A.G. Weed communities associated with arable Saskatchewan farm management systems. Can. J. Plant Sci., 80: 177-185 (2000).

Légere, A. and Samson, N. Relative influence of crop rotation, tillage, and weed management on weed associations in spring barley cropping systems. Weed Sci., 47: 112-122 (1999).

Madi, M. I.; Shaltout, K. H. and Sharaf El-Din, A. Flora of the coastal sand dunes of Gaza strip, Palastine. Proc. 2 nd Conf. Biol. Sci., Tanta Univ., 2: 64-78 (2002).

Magurran, A.E. Ecological Diversity and its Measurements. Croom. Helm., London, 179 pp (1988).

Marshall, E.J.P. Distribution patterns of plants associated with arable field edges. J. Appl. Ecol., 26: 247- 257 (1989).

Mashaly, I. A. Ecological and Floristic Studies of Dakahlia- Damietta Region. Ph.D. Thesis, Fac. Sci., Mansoura Univ., Mansoura, 282pp. (1987).

Muller-Dombois, D. and Ellenberg, H. Aims and Methods of Vegetation Ecology. John Wiley and Sons, New York (1974).

Palmer, M.W. and Maurer, T.A. Does diversity beget diversity? A case study of crops and weeds. J. Veg. Sci. 8: 235-240 (1997).

Patriquin D.G. "Biological husbandry and the nitrogen problem." In The Role of Microorganisms in a Sustainable Agriculture. Selected papers from The Second International Conference on Bioi. Agric., University of London, Wye College, Wye, Kent, UK. J.M. Lopez-Real, R.D. Hodges, eds. Berkamsted,: A.B. Academic, pp. 81103. Weed Effects on Soil Quality and Fertility (1986).

Pielou, E.C. Ecological Diversity. A Willy-Interscience Publication New York, 165 pp. (1975).

Pimienta-Barrios, E and Muñoz-Urias, A (1995).Domestication of opuntias and cultivated varieties. In:Agroecology, cultivation and uses of cactus pear(Barbera G, Inglese P, Pimienta, eds.). FAO Rome(Italy): 58-63 pp.

Pimienta-Barrios, E and Muñoz-Urias, A (1995).Domestication of opuntias and cultivated varieties. In:Agroecology, cultivation and uses of cactus pear(Barbera G, Inglese P, Pimienta, eds.). FAO Rome(Italy): 58-63 pp.

Pimienta-Barrios, E. and Muñoz-Urias, A. Domestication of opuntias and cultivated varieties. In:Agroecology, cultivation and uses of cactus pear(Barbera G, Inglese P, Pimienta, eds.). FAO Rome (Italy): 58-63 pp (1995). 
Sans, F.X. and Masalles, R.M. Phenological patterns in an arable land weed community related to disturbance. Weed Research, 35: 321-332 (1995).

Schmutz, E.M., Freeman, B.N. and Reed, R.E. Livestock Poisoning Plants of Arizona, (University of Arizona Press, Tucson), pp 153 (1968).

Shaltout, K.H. and El-Halawany, E.F. Weed communities of date palm orchards in eastern Arabia. Qatar Univ. Sci. J., 12: 105-111 (1992).

Shelef, O., Gross, A. and Rachmilevitch, Sh. Role of Plants in a Constructed Wetland: Current and New Perspectives. Water, 5: $405-419$ (2013).

Sher, H. and Al-Yemeni, M.N. Ecological investigation of the weed flora in arable and nonarable lands of Al-kharj area, Saudi Arabia. Afr. J. Agric. Res., 6 (4): 901-906 (2011).

Sieben, E.J.J., Collin, N.B., Corry, F.T.J., Kotze, D.C., Job, N., Muasya, A.M., Venter, C.E., Mtshali, H., Zondo, S.A., Janks, M. and Pretorius, L. The vegetation of grass lawn wetlands of floodplains and pans in semi-arid regions of South Africa: Description, classification and explanatory environmental factors. South African Journal of Botany, 104: 215-224 (2016).

Smith, L.L. Arbuscular mycorrhizal fungi and the competitiveness of the invasive vine PSW (Vincetoxicum rossicum). MSc Thesis. Ithaca, NY: CornellUniversity. 85 p. (2006).

Soliman, M.A. Composition and Function of Weed Communities Associated with Cereal Crops in Menofia Province, Egypt. M.Sc thesis, Botany Department, Faculty of Womwn for Arts Science and Education, Ain shams University, Cairo, Egypt (2016).

Spink, A.J. The Ecological Strategies of Aquatic Ranunculus Species. Ph.D. Thesis, Glasgow Univ., Glasgow (1992).

Springuel, I. and Murphy, K.J. Euhydrophyte Community of the River Nile and its Impoundment in Egyptian Nubia. Hydrobiol., 218: 35-47(1991).

Springuel, I. Riverian Vegetation in Nile Valley in Upper Egypt. J. Veg. Sci., 1: 595-598 (1990).

Springuel, I., El-Hadidi, M.N. and Ali, M.M. Vegetation Gradient on the Shores of Lake Nasser in Egypt. Vegetatio, 94: 15-21 (1991).

Stevenson, F.C., Legere, A., Simard, R.R., Angers, D.A., Pageau, D. and Lafond, J. Weed species diversity in spring barley varies with crop rotation and tillage, but not with nutrient source.Weed Sci., 45: 798-806 (1997).

Täckholm, V. Students Flora of Egypt. 2nd Edn., Cairo University Press, Egypt.(publ.), Cooperative Printing Company, Beirut, 888 pp (1974).

Tracy B.F., Renne I.J., Gerrish J., Sanderson M.A. Effects of plant diversity on invasion of weed species in experimental pasture communities. Basic Appl. Ecol., 5: 543-550 (2004).

Vigueras, AL, and Portillo, L (2001). Uses of Opuntia species and the potential impact of Cactoblastis cactorum in Mexico.Fla Entomol 84: 493- 498.

Vigueras, AL, and Portillo, L (2001). Uses of Opuntia species and the potential impact of Cactoblastis cactorum in Mexico.Fla Entomol 84: 493- 498.

Weston, L.A., Barney, J.N. and DiTommaso, A. A review of the biology, ecology and potential management of three important invasive perennials in New York State: Japanese knotweed (Polygonum cuspidatum), mugwort (Artemisia vulgaris) and pale swallowwort (Vincetoxicum rossicum). Plant Soil 277: 53-69 (2005).

Whittaker, G.H. Evolution and Measurement of Species Diversity. Taxon, 21: 231-251 (1972).

Zhang F. and Zhang J.T. Research progress of numerical classification and ordination of vegetation in China. J. Shanxi Univ. (Nat. Sci. Educ.) 23, 278-282 (2000). 


\section{الملخص باللغة العربية}

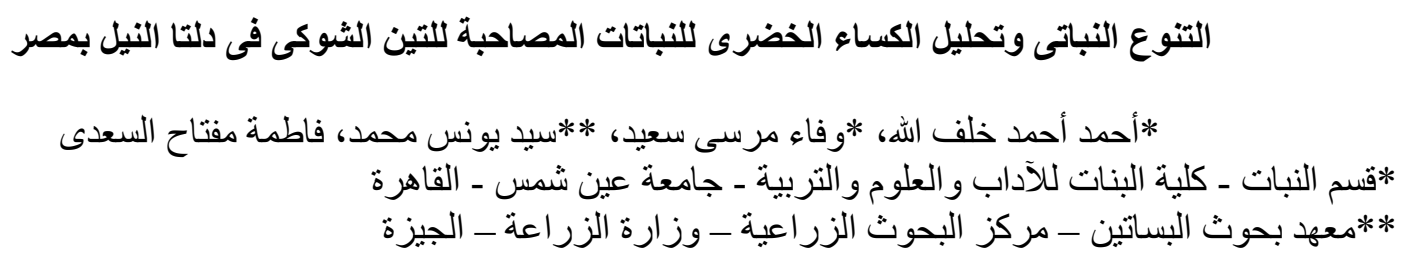

تهدف الدراسة الحالية إلى دراسة التتوع النباتى وتحليل الكساء الخضرى للنباتات المصاحبة للتين الثوكى فى ثلاثة محافظات تقع فى منطقة دلتا النيل (القليوبية - المنوفية - البحيرة). تم مسح 99 موقع (10م x x 10مى فى فصلى الخريف والربيع. نتج عن المسح تسجيل 71 نوعاً من النباتات المصاحبة للتين الثوكى تتنمى إلى 61 جنس و 27 عائلة. تمثل العائلة النجيلية إلى جانب المركبة والزربيحية والصليبية الأكثر سيادة من بين العائلات المسجلة. الحشائش الحولية تمنت العدد الأكبر ( 45 نوعاً) بينما النباتات المعمرة تمثل بـ 26 نوعاً. النباتات الحولية هى صاحبة السيادة بين صور الحياة الأحرى حيث مثلت بعدد 43 نوعاً كما تعتبر المجموعة الفلورية للنباتات ذات الانتثار المحدود بمنطقة فلورية أحادية هى السائدة من بين المجموعات الفلورية. وبتطبيق التحليل الدليلى ثثائى الاتجاه تم تسجيل 8 مجتمعات نباتية . وأوضحت الدراسة أن هناك علاقة ارتباط معنوية سلبية بين مساحة التغطية لأشجار التين الثوكى ومساحة التغطية للنباتات وعدد الأنواع ودلائل التتوع الحيوى. سجل فى هذه الدراسة عدد من الأنواع ذات التتافس القوى والضار لأشجار التين الثوكى وعلى رأسها العليق والبوص والحلفا لذلك يجب مقاومة انتشارها وسط الحدائق وكذلك سجل عدد كبير من أنواع الحشائش التى لها فوائد بيئية وطبية وليس لها تأثثر ضار معنوى على أشجار التين الثوكى لذلك يجب دراسة كيفية إدارتها والاستفادة منها. 